\title{
FAKTOR-FAKTOR YANG MEMPENGARUHI NILAI PERUSAHAAN PADA PERUSAHAAN NON KEUANGAN
}

\section{DEWI LUSIANA dan DEWI AGUSTINA}

\author{
STIE Trisakti \\ dewiagustina2780@yahoo.com
}

\begin{abstract}
The purpose of this research is to get empirical evidence about factorfactor which affect to firm value on non-financial companies. This research was conducted to determine the effect of managerial ownership, financial leverage, profitability, firm size, investment opportunity, dividend policy, intangible asset, liquidity ratio, and asset turnover to firm value. The samples in this research consist of 33 non-financial companies that have been listed in Indonesia Stock Exchanges (BEI) from period 2011 until 2014. Samples selected based on purposive sampling method with total 132 research data were used. The statistical used in this research was multiple regression method. The research showed that financial leverage, dividend policy, liquidity ratio, and asset turnover had no effect to firm value. Only managerial ownership, profitability, firm size, investment opportunity, and intangible asset had effect to firm value.
\end{abstract}

Keywords: Firm Value, Financial Leverage, Managerial Ownership, Profitability, Intangible Asset, Dividend Policy, Financial Performance, Investment Opportunity, Firm Characteristics

\begin{abstract}
Abstrak: Penelitian ini bertujuan untuk mendapatkan bukti empiris mengenai faktor-faktor yang mempengaruhi nilai perusahaan pada perusahaan non keuangan. Penelitian ini dilakukan untuk mengetahui pengaruh kepemilikan manajerial, leverage keuangan, profitabilitas, ukuran perusahaan, kesempatan investasi, kebijakan dividen, aset tidak berwujud, rasio likuiditas, dan perputaran asset terhadap nilai perusahaan. Sampel dalam penelitian ini meliputi 33 perusahaan non keuangan yang terdaftar di Bursa Efek Indonesia (BEI) dari periode 2011 sampai 2014. Sampel dipilih berdasarkan metode purposive sampling dengan total 132 data penelitian yang digunakan. Pengujian statistik dalam penelitian ini menggunakan metode regresi berganda. Penelitian menunjukkan bahwa kepemilikan leverage keuangan, kebijakan dividen, rasio likuiditas, dan perputaran aset tidak berpengaruh terhadap nilai perusahaan. Hanya kepemilikan manajerial, profitabilitas, ukuran perusahaan, kesempatan investasi, dan aset tidak berwujud yang berpengaruh terhadap nilai perusahaan.
\end{abstract}

Kata kunci: Nilai Perusahaan, Leverage Keuangan, Kepemilikan Manajerial, Profitabilitas, Aset Tidak Berwujud, Kebijakan Dividen, Kinerja Keuangan, Kesempatan Investasi, Karakteristik Perusahaan. 


\section{PENDAHULUAN}

Nilai perusahaan akan mempengaruhi persepsi dari para investor serta calon investor terhadap suatu perusahaan. Nilai perusahaan sangat penting karena dengan nilai perusahaan yang tinggi akan diikuti oleh tingginya kemakmuran dari para pemegang saham. Semakin tinggi harga saham maka nilai perusahaan juga akan semakin tinggi. Salah satu perusahaan BUMN yang terdaftar di Bursa Efek Indonesia (BEI) yang berhasil masuk peringkat "Fortune Global 500" pada pertengahan Juli 2013 untuk pertama kali karena kinerjanya adalah PT Pertamina (Persero) Tbk.

McConnell and Servaes (1990) menyatakan bahwa kepemilikan manajerial dapat mengoptimalisasi nilai perusahaan. Hal ini dikarenakan kepemilikan manajerial dapat mempengaruhi kinerja perusahaan serta memaksimalkan nilai perusahaan di bawah pengawasan dan kontrol dari manajemen.

Davies et al. (2005) menyatakan bahwa leverage keuangan juga dapat meningkatkan nilai perusahaan, karena peningkatan atas utang akan meningkatkan nilai perusahaan yang diartikan oleh pihak eksternal perusahaan sebagai kemampuan dari suatu perusahaan dalam membayar kewajibannya di masa depan atau akan diartikan sebagai perusahaan tersebut memiliki resiko bisnis yang rendah.

Chen and Steiner (2000) menyatakan bahwa profitabilitas dapat meningkatkan nilai perusahaan, karena semakin besar suatu perusahaan memperoleh laba akan mencerminkan kinerja dari perusahaan tersebut semakin baik serta akan menggambarkan keadaan perusahaan tersebut dimasa yang akan datang di mata investor.

Nuraina (2012) menyatakan bahwa ukuran perusahaan juga dapat meningkatkan nilai perusahaan, karena perusahaan besar dapat dengan mudah mengakses ke pasar modal yang berarti perusahaan memiliki fleksibilitas dan kemampuan untuk mendapatkan dana, sehingga memberikan sinyal positif kepada investor yang dapat meningkatkan nilai perusahaan.
Itturiaga and Sanz (2001) menyatakan bahwa semakin tinggi kesempatan investasi, semakin tinggi juga nilai perusahaan. Ketika suatu perusahaan akan melakukan investasi, manajemen akan membuat keputusan untuk memilih salah satu atau lebih dari satu alternatif investasi yang dinilai akan memberikan keuntungan bagi perusahaan yang memberikan prospek yang menguntungkan di masa depan.

Omran and Pointon (2004) menyatakan bahwa kebijakan dividen juga dapat meningkatkan nilai perusahaan. Kebijakan dividen akan melibatkan banyak pihak yang terkait yaitu pemegang saham. Bagi para pemegang saham, mereka dapat meningkatkan kesejahteraan dengan memperoleh return atas dana yang telah mereka investasikan dalam suatu perusahaan, tetapi bagi pihak manajemen kesejahteraan dapat diperoleh yaitu dengan adanya investasi yang berpotensi untuk meningkatkan nilai perusahaan. Return adalah jumlah laba atau rugi yang diperoleh dari total distribusi kas dari investasi ditambah perubahan nilai investasi dalam suatu periode dibagi nilai investasi awal periode (Gitman dan Zutter 2012, 311).

Penelitian ini merupakan pengembangan penelitian Rizqia et al. (2013) yang menggunakan 9 variabel independen dimana penelitian ini akan menambahkan 3 variabel independen baru yaitu aset tidak berwujud, rasio likuiditas, dan perputaran aset yang diambil dari penelitian Gamayuni et al. (2015).

Alasan yang mendasari penelitian ini karena ketidakkonsistenan hasil penelitianpenelitian sebelumnya sehingga menyebabkan hasil yang tidak mutlak. Penelitian Haruman (2007) mengemukakan bahwa kebijakan dividen berpengaruh negatif terhadap nilai perusahaan. Penelitian Juhandi et al. (2013) menyatakan bahwa kepemilikan manajerial berpengaruh negatif terhadap nilai perusahaan.Oleh karena itu, hal ini mendorong penulis untuk melakukan pengembangan penelitian untuk memberikan hasil penelitian yang berbeda dengan penelitian sebelumnya. 
Berdasarkan latar belakang penelitian tersebut maka dapat dikemukakan beberapa permasalahan sebagai berikut apakah kepemilikan manajerial, leverage, profitabilitas,ukuran perusahaan,kesempatan investasi, kebijakan dividen, aset tidak berwujud, rasio likuiditas, perputaran aset berpengaruh terhadap nilai perusahaan.

Berdasarkan masalah penelitian yang akan diteliti maka dapat ditentukan tujuan penelitian yakni, untuk mendapatkan bukti empiris mengenai pengaruh kepemilikan manajerial, leverage, profitabilitas, ukuran perusahaan, kesempatan investasi, kebijakan dividen, aset tidak berwujud, rasio likuiditas, perputaran aset berpengaruh terhadap nilai perusahaan.

Manfaat bagi investor dalam penelitian ini yakni dapat digunakan sebagai bahan kajian untuk pertimbangan saat melakukan investasi. Sedangkan untuk manajemen perusahaan diharapkan dapat digunakan sebagai pertimbangan bagi manajemen perusahaan dalam mengaplikasikan variabel-variabel penelitian ini dalam meningkatkan kinerja para manajer agar nilai perusahaan meningkat serta sebagai bahan pertimbangan emiten untuk mengevaluasi, memperbaiki, dan meningkatkan kinerja manajemen di masa yang akan datang. Manfaat lain bagi kreditur diharapkan dapat menjadi pertimbangan para kreditur dalam memberikan modal pinjaman serta dapat digunakan untuk menentukan kredibilitas perusahaan. Sedangkan bagi peneliti selanjutnya diharapkan dapat digunakan sebagai sumber informasi dan referensi untuk menambah pengetahuan dan pemahaman serta bahan diskusi atau pembanding bagi peneliti selanjutnya yang akan meneliti bahasan yang serupa.

\section{Teori Keagenan}

Teori keagenan merupakan konsep yang menjelaskan hubungan kontraktual antara principals dan agents. Pihak principals merupakan pemegang saham sedangkan, pihak agent adalah manajemen. Hubungan keagenan akan timbul dimana terdapat satu pihak (pihak principal) yang terlibat dengan pihak lain (pihak agent) untuk melakukan beberapa pelayanan atas nama pihak principal yang melibatkan pendelegasian sebagai wewenang dalam pengambilan keputusan terhadap pihak agent (Jensen dan Meckling 1976).

\section{Teori pesinyalan}

Godfrey et al. $(2010,375)$ mengemukakan bahwa teori pesinyalan menekankan kepada pentingnya informasi yang dikeluarkan oleh perusahaan terhadap keputusan investasi pihak di luar perusahaan. Informasi merupakan unsur penting bagi investor dan pelaku bisnis karena informasi pada hakikatnya menyajikan keterangan, catatan atau gambaran baik untuk keadaan masa lalu, saat ini maupun keadaan masa yang akan datang bagi kelangsungan hidup suatu perusahaan dan bagaimana pasaran efeknya. Informasi yang lengkap, relevan, akurat dan tepat waktu sangat diperlukan oleh investor di pasar modal sebagai alat analisis untuk mengambil keputusan investasi.

\section{Nilai Perusahaan}

Nilai perusahaan merupakan persepsi investor atas kondisi keuangan perusahaan.Nilai perusahaan terlihat dari memaksimumkan harga saham perusahaan. Memaksimalkan nilai perusahaan sangat penting bagi suatu perusahaan, karena dengan memaksimalkan nilai perusahaan berarti perusahaan juga memaksimalkan kemakmuran pemegang saham (Gultom et al. 2013).

\section{Kepemilikan Manajerial}

Kepemilikan manajerial adalah kepemilikan saham oleh manajemen perusahaan yang diukur dengan persentase jumlah saham yang dimiliki oleh manajemen. Meningkatnya kepemilikan manajerial perusahaan dapat digunakan sebagai salah satu cara mengatasi masalah yang ada pada perusahaan. Dengan meningkatnya kepemilikan manajerial maka manajer akan termotivasi untuk meningkatkan kinerjanya, sehingga dalam hal ini akan berdampak baik bagi perusahaan serta dapat memenuhi keinginan para pemegang saham di perusahaan. 


\section{Leverage Keuangan}

Leverage keuangan digunakan untuk mengukur kemampuan perusahaan untuk bertahan dalam jangka panjang. Kreditur dan pemegang saham sangat tertarik pada kemampuan perusahaan untuk membayar bunga serta nilai nominal utang yang jatuh tempo.

\section{Profitabilitas}

Profitabilitas adalah tingkat keuntungan bersih yang mampu diraih oleh perusahaan pada saat menjalankan operasinya. Semakin besar keuntungan yang diperoleh, maka semakin besar kemampuan perusahaan untuk membagikan dividen. Semakin besar dividen yang dibagikan kepada para pemegang saham, maka akan semakin tinggi nilai perusahaan. Selain itu laba yang tinggi juga akan memberikan prospek yang perusahaan yang baik, sehingga dapat menarik investor untuk ikut meningkatkan permintaan saham. Permintaan saham yang meningkat akan menyebabkan nilai perusahaan yang meningkat (Nurhayati 2013).

\section{Ukuran Perusahaan}

Ukuran perusahaan adalah suatu skala dimana dapat diklasifikasikan besar kecilnya perusahaan. Ukuran perusahaan dapat dibedakan dalam dua kategori, yaitu perusahaan besar dan perusahaan kecil (Godfrey et al. 2010, 415). Dalam hal ini menunjukkan bahwa ukuran perusahaan merupakan suatu indikator yang dapat menunjukkan suatu kondisi atau karakteristik suatu perusahaan.

\section{Kesempatan Investasi}

Kesempatan investasi membantu manajer dalam menggunakan sumber daya yang dimiliki oleh perusahaan secara efisien. Kesempatan investasi harus dipertimbangkan secara cermat agar memberikan manfaat yang menguntungkan bagi perusahaan dimasa yang akan datang. Semakin tinggi keuntungan yang diperoleh oleh perusahaan, maka akan semakin besar kemakmuran yang diterima oleh pemegang saham yang akan menimbulkan terjadinya peningkatan nilai perusahaan (Gustiandika dan Hadiprajitno 2014).

\section{Kebijakan Dividen}

Kebijakan dividen merupakan bagian yang tidak dapat dipisahkan dengan keputusan pendanaan perusahaan. Kebijakan dividen adalah keputusan apakah laba yang diperoleh suatu perusahaan pada akhir tahun akan dibagi kepada para pemegang saham dalam bentuk dividen atau akan ditahan untuk menambah modal untuk pembiayaan investasi dimasa yang akan datang (Bernandhi dan Muid 2014).

\section{Aset Tidak Berwujud}

Aset tidak berwujud adalah hak, hak istimewa, dan keunggulan kompetitif yang merupakan hasil dari kepemilikan aset jangka panjang yang tidak memiliki substansi fisik. Bukti dari aset tidak berwujud yang nyata adalah dalam bentuk kontrak atau lisensi (Weygandt et al. 2013, 428).

\section{Rasio Likuiditas}

Rasio likuiditas ini juga berpengaruh terhadap kinerja keuangan perusahaan sehingga berhubungan dengan harga saham perusahaan. Semakin besar aset lancar dan kewajiban lancar akan semakin tinggi juga kemampuan perusahaan dapat menutupi kewajiban jangka pendeknya (Weygandt et al. 2013, 696).

\section{Perputaran Aset}

Perputaran aset menggambarkan efektivitas penggunaan seluruh ekuitas perusahaan dalam rangka menghasilkan penjualan. Apabila perusahaan memiliki kemampuan untuk mendapatkan pendapatan yang lebih tinggi, maka perputaran aset akan lebih efisien dan laba akan meningkat. Meningkatnya laba akan membuat nilai perusahaan meningkat (Hidayah 2014).

\section{Pengembangan Hipotesis}

Berdasarkan penelitian-penelitian sebelumnya, berikut ini rumusan beberapa hipotesis:

$\mathrm{H}_{1} \quad$ Kepemilikan manajerial mempengaruhi nilai perusahaan.

$\mathrm{H}_{2}$ Leverage keuangan mempengaruhi nilai perusahaan. 
$\mathrm{H}_{3} \quad$ Profitabilitas mempengaruhi nilai perusahaan.

$\mathrm{H}_{4}$ Ukuran perusahaan mempengaruhi nilai perusahaan.

$\mathrm{H}_{5} \quad$ Kesempatan investasi mempengaruhi nilai perusahaan.

$\mathrm{H}_{6} \quad$ Kebijakan dividen mempengaruhi nilai perusahaan.

$\mathrm{H}_{7} \quad$ Aset tidak berwujud mempengaruhi nilai perusahaan.

$\mathrm{H}_{8} \quad$ Rasio likuiditas mempengaruhi nilai perusahaan.

$\mathrm{H}_{9} \quad$ Perputaran aset mempengaruhi nilai perusahaan.

\section{METODA PENELITIAN}

Populasi dalam penelitian ini adalah seluruh perusahaan yang terdaftar di Bursa Efek Indonesia (BEI). Sampel yang dipilih dalam penelitian ini adalah perusahaan non keuangan yang terdaftar di Bursa Efek Indonesia (BEI).Periode yang digunakan adalah empat tahun yaitu 2011 sampai dengan 2014.Metode pemilihan sampel menggunakan purposive sampling yaitu pengambilan sampel yang diambil secara tidak acak dan informasinya diperoleh dengan kriteria tertentu, tetapi pada umumnya disesuaikan dengan tujuan atau masalah yang ingin dilakukan penelitian ini (Sekaran dan Bougie 2013, 252).

$$
\text { DAR }=\frac{\text { Total utang }}{\text { Total aset }}
$$

Nilai perusahaan adalah variabel dependen yang diukur dengan menggunakan rasio Tobin's $Q$ dalam Rizqia et al. (2013). Skala yang digunakan dalam penelitian ini adalah skala rasio. Cara pengukuran Tobin's $Q$ adalah sebagai berikut:

Nilai Perusahaan $=$

(Market value of equity + Book Value of equity)

Book value of asset

Kepemilikan manajerial diukur berdasarkan persentase kepemilikan saham oleh institusi perusahaan. Skala pengukuran variabel independen ini adalah skala rasio. Rumus untuk menghitung persentase kepemilikan manajerial berdasarkan penelitian Rizqia et al. (2013) adalah sebagai berikut:
Kepemilikan Manajerial =

$$
\begin{aligned}
& \begin{array}{c}
\text { Jumlah saham yang dimiliki oleh } \\
\text { anggota komisaris dan direktur }
\end{array} \\
& \text { Jumlah saham biasa yang beredar }
\end{aligned}
$$

Leverage adalah rasio yang menunjukkan kemampuan perusahaan untuk memenuhi segala kewajiban finansialnya jika perusahaan tersebut mengalami likuidasi (Gitman dan Zutter 2012, 560). Variabel leverage keuangan diukur dengan debt to total asset ratio (DAR) yaitu total utang jangka panjang dibagi dengan total aset. Pengukuran variabel leverage keuangan dilakukan dalam penelitian Rizqia et al. (2013) yang menggunakan skala rasio, dengan rumus sebagai berikut:

$$
\mathrm{ROA}=\frac{\text { Net Income }}{\text { Total asset }}
$$

Profitabilitas dapat diukur dengan menggunakan return on asset (ROA). Return on asset (ROA) menggambarkan kinerja keuangan perusahaan dalam menghasilkan laba bersih dari aset yang digunakan untuk operasional perusahaan (Gitman dan Zutter 2012, 130).

Dalam penelitian Rizkia et al. (2013) menyatakan bahwa ukuran perusahaan adalah ukuran yang menunjukkan level dari sebuah perusahaan dalam bisnis. Dimana skala pengukuran yang dilakukan adalah skala rasio. Pengukuran ukuran perusahaan yang dinyatakan dalam Rizqia et al. (2013) adalah sebagai berikut :

$$
\text { Firm Size }=\text { Ln (Total Asset })
$$

Kesempatan investasi merupakan keputusan investasi dalam bentuk gabungan dari aset yang dimiliki perusahaan dan pilihan investasi masa depan dengan keuntungan (Rizqia et al. 2013). Skala pengukuran yang digunakan adalah skala rasio. Pengukuran variabel ini diambil dari penelitian yang dilakukan oleh Rizqia et al. (2013) dengan rumus sebagai berikut: 
Kesempatan Investasi $=$

Book value of fixed asset $t_{t}+$ Book value of fixed asset $t_{t-1}$

Total Asset $t_{t}$

Menurut Rizqia et al. (2013), kebijakan dividen merupakan kebijakan yang dibuat berdasarkan pengalokasian net income yang dihasilkan dari aktivitas-aktivitas operasi perusahaan untuk dibagikan dalam bentuk retained earnings. Pengukuran variabel kebijakan dividen diukur dengan diambil penelitian yang dilakukan oleh Rizqia et al. (2013) dengan menggunakan skala rasio dengan rumus :

$$
\mathrm{DPR}=\frac{\text { Dividend per share }}{\text { Earnings per share }}
$$

PSAK No 19 menjelaskan bahwa aset tidak berwujud adalah aset yang memiliki karakteristik non-monetary assets, teridentifikasi dan tanpa wujud fisik (Ikatan Akuntan Indonesia 2014, 19.3). Skala pengukuran variabel independen ini adalah skala rasio. Pengukuran variabel aset tidak berwujud diambil dari penelitian yang dilakukan oleh Gamayuni et al. (2015) dengan menggunakan value of intangible assets dengan rumus sebagai berikut:

Value Of Intangible Assets =

$$
\begin{gathered}
\text { Market Value of equity (MVE) - Book value of } \\
\text { equity (BVE) }
\end{gathered}
$$

Menurut Gamayuni et al. (2015), rasio likuiditas merupakan aset lancar yang tersedia yang dapat memenuhi utang lancar yang ada dalam suatu perusahaan. Skala pengukuran variabel independen ini adalah skala rasio. Pengukuran variabel rasio likuiditas diukur dengan diambil penelitian yang dilakukan oleh Gamayuni et al. (2015) dengan menggunakan current ratio dengan rumus sebagai berikut:

$$
\text { Current Ratio }=\frac{\text { Current Assets }}{\text { Current Debt }}
$$

Menurut Gamayuni et al. (2015), perputaran aset merupakan keefektifan atas aset dan aset yang terperinci dalam penjualan secara umum. Skala pengukuran variabel independen ini adalah skala rasio. Pengukuran variabel perputaran aset diukur dengan diambil penelitian yang dilakukan oleh Gamayuni et al. (2015) dengan menggunakan asset turnover dengan rumus sebagai berikut :

$$
\text { Asset Turnover }=\frac{\text { Sales }}{\text { Total Assets }}
$$

\section{HASIL PENELITIAN}

Hasil pengujian hipotesis menunjukkan variabel koefisien MOWN (kepemilikan manajerial) memiliki nilai signifikansi 0,002 lebih kecil dari alpha $(\alpha=0,05)$, maka dapat dijelaskan bahwa $\mathrm{H}_{1}$ dapat diterima. Hal ini berarti kepemilikan manajerial mempengaruhi nilai perusahaan. Nilai koefisiensi MOWN sebesar -9,967 menunjukkan bahwa kepemilikan manajerial memiliki pengaruh negaatif. Hal ini menunjukkan adanya kepemilikan saham yang dimiliki oleh manajemen dapat menyelaraskan kepentingan antara manajemen dan pemegang saham, sehingga nilai perusahaan dapat ikut meningkat.

Koefisien DAR (leverage keuangan) memiliki nilai signifikansi 0,269 lebih besar dari alpha $(\alpha=0,05)$, maka dapat dijelaskan bahwa $\mathrm{H}_{2}$ belum dapat diterima. Hal ini berarti leverage keuangan tidak mempengaruhi nilai perusahaan.

Koefisien ROA (profitabilitas) memiliki nilai signifikansi 0,000 lebih kecil dari alpha $(\alpha=$ $0,05)$, maka dapat dijelaskan bahwa $\mathrm{H}_{3}$ dapat diterima. Hal ini berarti profitabilitas mempengaruhi nilai perusahaan. Nilai koefisien ROA sebesar 20,718 menunjukkan bahwa profitabilitas memiliki pengaruh positif. Hal ini menunjukkan bahwa meningkatnya laba dari suatu perusaha- 
an akan memberikan sinyal positif bagi investor karena kinerja perusahaan yang meningkat akan memberikan dampak terhadap kesejahteraan para pemegang saham.

Koefisien SIZE (ukuran perusahaan) memiliki nilai signifikansi 0,000 lebih kecil dari alpha $(\alpha=0,05)$, maka dapat dijelaskan bahwa $\mathrm{H}_{4}$ dapat diterima. Hal ini berarti ukuran perusahaan mempengaruhi nilai perusahaan. Nilai koefisien SIZE sebesar -0,395 menunjukkan bahwa ukuran perusahaan memiliki pengaruh negatif. Hal ini menunjukkan bahwa investor dalam mengambil keputusan tidak hanya melihat seberapa besar aset yang dimiliki perusahaan, tetapi juga dari laporan keuangan, nama baik perusahaan, dan kebijakan dividen peusahaan tersebut.

Koefisien CAPEX (kesempatan investasi) memiliki nilai signifikansi 0,004 lebih kecil dari alpha $(\alpha=0,05)$, maka dapat dijelaskan bahwa $\mathrm{H}_{5}$ dapat diterima. Hal ini berarti kesempatan investasi mempengaruhi nilai perusahaan. Nilai koefisien CAPEX sebesar -1,296 menunjukkan bahwa kesempatan investasi memiliki pengaruh negatif. Hal ini menunjukkan bahwa kesempatan investasi yang dengan tingkat risiko yang ditanggung dimasa yang akan datang akan sama besarnya dengan investasi yang dilakukan, sehingga akan mempengaruhi tingkat kepercayaan para investor dalam melakukan investasi.

Koefisien DPR (kebijakan dividen) memiliki nilai signifikansi 0,128 lebih besar dari alpha $(\alpha=0,05)$, maka dapat dijelaskan bahwa $\mathrm{H}_{6}$ belum dapat diterima. Hal ini berarti kebijakan dividen tidak mempengaruhi nilai perusahaan.

Koefisien IA (aset tidak berwujud) memiliki nilai signifikansi 0,000 lebih kecil dari alpha $(\alpha=0,05)$, maka dapat dijelaskan bahwa $\mathrm{H}_{7}$ dapat diterima. Hal ini berarti aset tidak berwujud mempengaruhi nilai perusahaan. Nilai koefisien IA sebesar 0,0000000000000251 menunjukkan bahwa aset tidak berwujud memiliki pengaruh positif. Hal ini menunjukkan bahwa dengan adanya aset tidak berwujud seperti inovasi, teknologi baru, dan kemampuan serta pengetahuan para karyawan yang luas akan memberikan kesuksesan terhadap perusahaan, sehingga nilai perusahaan akan meningkat.

Koefisien CR (rasio likuiditas) memiliki nilai signifikansi 0,755 lebih besar dari alpha ( $\alpha=$ $0,05)$, maka dapat dijelaskan bahwa $\mathrm{H}_{8}$ belum dapat diterima. Hal ini berarti rasio likuiditas tidak mempengaruhi nilai perusahaan.

Koefisien AST (perputaran aset) memiliki nilai signifikansi 0,097 lebih besar dari alpha $(\alpha=0,05)$, maka dapat dijelaskan bahwa $\mathrm{H}_{9}$ belum dapat diterima. Hal ini berarti perputaran aset tidak mempengaruhi nilai perusahaan.

\section{PENUTUP}

Berdasarkan pengujian regresi yang telah dilakukan hasilnya menunjukkan Kepemilikan manajerial mempengaruhi nilai perusahaan. Leverage keuangan tidak mempengaruhi nilai perusahaan. Profitabilitas mempengaruhi nilai perusahaan. Ukuran perusahaan mempengaruhi nilai perusahaan. Kesempatan investasi mempengaruhi nilai perusahaan.Kebijakan dividen tidak mempengaruhi nilai perusahaan.Aset tidak berwujud mempengaruhi nilai perusahaan. Rasio likuiditas tidak mempengaruhi nilai perusahaan. Perputaran aset tidak mempengaruhi nilai perusahaan.

Penelitian ini memiliki beberapa keterbatasan yakni penelitian ini hanya mengambil sampel perusahaan non keuangan yang terdaftar di Bursa Efek Indonesia sebagai objek penelitian, sehingga hasil dari penelitian yang dilakukan tidak dapat digeneralisasi ke sektor industri lain. Keterbatasan lainnya periode penelitian yang digunakan dalam melakukan pengujian hanya mencakup 4 tahun yaitu dari tahun 2011 sampai dengan 2014. Dalam uji asumsi klasik terdapat variabel yang tidak memenuhi uji heteroskedastisitas yaitu profitabilitas dan aset tidak berwujud. Sedangkan penelitian ini hanya menggunakan 9 variabel sebagai variabel independen.yakni kepemilikan manajerial, leverage keuangan, profitabilitas, ukuran perusahaan, kesempatan investasi, kebijakan dividen, aset tidak berwujud, likuiditas. 
Penelitian selanjutnya diharapkan peneliti bisa memperluas objek penelitian yang tidak terbatas pada perusahaan non keuangan, tetapi juga pada sektor industri lainnya yang terdaftar di Bursa Efek Indonesia, sehingga dapat memberikan gambaran yang lebih luas mengenai nilai perusahaan. Peneliti juga bisa memperpanjang periode penelitian dalam pene- litian selanjutnya, misalnya lima sampai enam tahun. Peneliti selanjutnya diharapkan memperbanyak data penelitian dalam rangka mengatasi masalah terjadinya heteroskedastisitas serta peneliti selanjutnya diharapkan menambahkan variabel independen lainnya, seperti kepemilikan institusional dan growth.

\section{REFERENSI:}

Achmad dan Amanah. 2014. Pengaruh Keputusan Investasi, Keputusan Pendanaan, Kebijakan Dividen dan Kinerja Keuangan terhadap Nilai Perusahaan. Jurnal IImu dan Riset Akuntansi. Vol. 3, No. 9: 1-15.

Aivazian, V., Laurence B., and Sean Cleary. 2003. Do Emerging Market Firms Follow Different Dividend Policies From U.S. Firms?. The Journal of Financial Research. Vol. 26, №. 3: 371-387.

Al-Najjar, Basil. (2009). Dividend behavior And Smoothing New Evidence From Jordanian Panel Data. Studies in and Finance. Vol. 26, No. 3: 182-197.

Anzlina, Corry Winda dan Rustam. 2013. Pengaruh Tingkat Likuiditas, Solvabilitas, Aktivitas, dan Profitabilitas terhadap Nilai Perusahaan pada Perusahaan Real Estate dan Property Di BEI Tahun 2006-2008. Jurnal Ekonom. Vol. 16, No. 2: 67-75.

Bashir, Hamid, Khurram Sultan, dan Omar Khazaal Jghef. 2013. Impact of Derivatives Usage on Firm Value: Evidence from Non Financial Firms of Pakistan. Journal of Management Research. Vol. 5, No.4: 108-127.

Benson, Bradley W. and Davidson III, W.N. 2009. Reexamining The Managerial Ownership Effect on Firm Value. Journal of Corporate Finance. Vol. 5: 573-586.

Bernandhi, Riza dan Abdul Muid. 2014. Pengaruh Kepemilikan Manajerial, Kepemilikan Institusional, Kebijakan Dividen, Leverage, dan Ukuran Perusahaan terhadap Nilai Perusahaan. Diponegoro Journal of Accounting. Vol. 3, No. 1: 1-14.

Chen, C.R. and Thomas L. Steiner. 2000. Tobin's Q, Managerial Ownership, and Analyst Coverage: A Non Linear Simultaneous Equations Model. Journal of Economics and Business, No. 52: 365-382.

Chen, Xudong, Na Hu, Xue Wang, and Xiaofei Tang. 2014. Tax Avoidance and Firm Value: Evidence from China. Nankai Business Review International. Vol. 5, No. 1: 25-42.

Chowdhury, Anup and Suman Paul Chowdhury. 2010. Impact of Capital Structure on Firm's Value: Evidence from Bangladesh. BEH - Business and Economic Horizons. Vol. 3, No.3: 111-122.

Chung, K.H. and Pruit, S.W. 1994. A Simple Approximation Of Tobin's Q. Financial Management. Vol. 23, No. 3: 70-74.

Chung, K.H., Peter Wright, and Charlie Charoenwong. 1998. Investment Opportunities and Market Reaction to Capital Expenditure Decision. Journal of Banking and Finance. No. 22: 41-60.

Crutchley, C. E. and Robert S. Hansen. 1989. A Test Of The Agency Theory of Managerial Ownership, Corporate Leverage, and Corporate Dividends. Financial Management/Winter. Vol. 18, No. 4: 36-46.

Davies, J.R., Hillier, D. and McColgan, P. 2005. Ownership Structure, Managerial Behavior, and Corporate Value. Journal of Corporate Finance. No. 11: 645-660.

Dewi, Lini Novita dan Ketut Alit Suardana.2015. Pengaruh Keputusan Investasi dan Good Corporate Governance pada Kinerja Keuangan serta Implikasinya pada Nilai Perusahaan. E-jurnal Akuntansi Universitas Udayana. Vol. 12, No. 3: 786- 802.

Fallatah, Yaser and Denise Dickins. 2012. Corporate Governance and Firm Performance and Value in Saudi Arabia. African Journal of Business Management. Vol. 6, No. 36: 10025-10034.

Fenandar, Gany Ibrahim dan Surya Raharja. 2012. Pengaruh Keputusan Investasi, Keputusan Pendanaan, dan Kebijakan Dividen terhadap Nilai Perusahaan. Diponegoro Journal of Accounting. Vol. 1, No. 2: 1-10. 
Gamayuni, Rindu Rika. 2015. The Effect of Intangible Asset, Financial Performance and Financial Policies on the Firm Value. International Journal of Scientific \& Technology Research. Vol. 4, No. 1: $202-212$.

Gitman, Lawrence J., dan Chad J. Zutter. 2015. Principles of Managerial Finance 14th Edition. New York: Pearson Education.

Gultom, Robinhot, Agustina, dan Sri Widia Wijaya. 2013. Analisis Faktor-Faktor yang mempengaruhi Nilai Perusahaan pada Perusahaan Farmasi Bursa Efek Indonesia.Jurnal Wira Ekonomi Mikroskil. Vol 3, No. 1: 51-60.

Gustiandika, Tito dan P. Basuki Hadiprajitno.2014. Pengaruh Keputusan Investasi dan Keputusan Pendanaan terhadap Nilai Perusahaan dengan Corporate Governance sebagai Variabel Moderating.Diponegoro Journal of Accounting. Vol. 3, No. 2: 1-12.

Ghosh, Saurabh and Arijit Ghosh. 2008. Do Leverage, Dividend Policy and Profitability Influence the Future Value of Firm ? Evidence from India. Indira Gandhi Institute of Development Research.

Ghozali, Imam. 2013. Aplikasi Analisis Multivariate dengan Program IBM SPSS 21. Semarang: Penerbit Universitas Diponegoro.

Haruman, Tendi. 2007. Effect of Financial Decisions and Institutional Ownership on Corporate Value (Case Study In A Manufacturing Company Listing on the JSE) The $1^{\text {st }}$ National Conference on PPM Management Research' Management in the Era of Globalization "PPM School of Management, 7 November 2007.

Hermuningsih, Sri dan Dewi Kusuma Wardani. 2009. Faktor-faktor yang mempengaruhi Nilai Perusahaan pada Perusahaan yang Terdaftar di Bursa Efek Malaysia dan Bursa Efek Indonesia. Jurnal Siasat Bisnis. Vol. 13, No. 2: 173-183.

Hidayah, Nurul. 2014. The Effect of Company Characteristic toward Firm Value in The Property and Real Estate Company in Indonesia Stock Exchange. International Journal of Business, Economic and Law. Vol. 5 , No. 1: 1-8.

Indrajaya, Glenn, Herlina, dan Rini Setiadi. 2011. Pengaruh Struktur Aktiva, Ukuran Perusahaan, Tingkat Pertumbuhan, Profitabilitas Risiko Bisnis Terhadap Struktur Modal: Studi Empiris Pada Perusahaan Sektor Pertambangan yang Listing di Bursa Efek Indonesia Periode 2004-2007. Akurat Jurnal IImiah Akuntansi. No. 6: 1-23.

Iturriaga, F.J.L. and Juan Antonio R. Sanz. 2001. Ownership Structure, Corporate Value, And Firm Investment: A Simultaneous Equations Analysis of Spanish Companies. Journal of Management and Governance, No. 5: 179-204.

Jensen, M.C. 1986. Agency Costs Of Free Cash Flow, Corporate Finance, and Takeovers. The American Economic Review. Vol. 76, No. 2: 323-329.

Jensen, M.C. and Meckling, W.H. 1976. Theory of the firm: Managerial Behavior, Agency Costs and Ownership Structure. Journal of Financial Economics. Vol. 3, No. 4: 305-360.

Juhandi, Nendi, Made Sudarma, Siti Aisjah, dan Rofiaty. 2013. The Effects of Internal Factors and Stock Ownership Structure on Dividend Policy on Company's Value [A Study on Manufacturing Companies Listed on the Indonesia Stock Exchange (IDX)]. International Journal of Business and Management Invention. Vol. 2, No. 11: 6-18.

Khafa, Lais dan Herry Laksito. 2015. Pengaruh CSR, Ukuran Perusahaan, Leverage, dan Keputusan Investasi pada Kinerja Keuangan Perusahaan dan Nilai Perusahaan. Diponegoro Journal of Accounting. Vol. 4, No. 4: 1-13.

Kumar, Naveen and J. P. Singh. 2013. Effect of Board Size and Promoter Ownership on Firm Value: Some Emperical findings from India. Corporate Governance. Vol. 13, No. 1: 88-98.

Kusumaningrum, Dyah Ayu Ratnasari dan Shiddiq Nur Rahardjo. 2013. Pengaruh Keputusan Investasi, Keputusan Pendanaan, Kebijakan Dividen, Kepemilikan Manajerial, dan Kepemilikan Institusional terhadap Nilai Perusahaan. Diponegoro Journal of Accounting. Vol. 2, No. 4: 1-10.

Lang, Harry H.P. dan Rene M. Stulz. 1994. Tobin's Q, Corporate Diversification, and Firm Performance. The Journal of Political Economy. Vol. 102, No. 6: 1248-1280.

Lantz, Jean-Sébastien and Jean-Michel Sahut. 2005. R \& D Investment and the Financial of Performance of Technological Firms. International Journal of Business. Vol. 10, No. 4: 1-20. 
Malan, Irfah Najihah Basir Malan, Norhana Salamudin dan Noryati Ahmad. 2013. Ownership and Control Divergence in Firm Value. Indian Journal of Commerce \& Management Studies. Vol. 4, No. 1: 78-85.

Mangatar, Maryam dan Muhammad Ali. 2015. An Analysis of the Influence of Ownership Structure, Investment, Liquidity and Risk to Firm Value: Evidence from Indonesia. American Journal of Economics and Business Administration. Vol. 7, No. 4: 166-176.

McConnell, J.J. and Henri Servaes. 1990. Additional evidence on equity ownership and corporate value. Journal of Financial Economics. No. 27: 595-612.

Mehta, Anupam. 2012. An empirical analysis of determinants of dividend policy-evidence from the UAE companies. Global Review of Accounting and Finance. Vol. 3, No. 1: 18-31.

Nuraina, Elva. 2012. Pengaruh Kepemilikan Institusional dan Ukuran Perusahaan terhadap Kebijakan Hutang dan Nilai Perusahaan (Studi pada Perusahaan Manufaktur yang tercatat di BEI).Jurnal Bisnis dan Ekonomi (JBE). Vol. 19, No. 2: 110-125.

Nurhayati, Mafizatun. 2013. Profitabilitas, Likuiditas, dan Ukuran Perusahaan pengaruhnya terhadap Kebijakan Dividen dan Nilai Perusahaan Sektor Non Jasa. Jurnal Keuangan dan Bisnis. Vol. 5, No. 2: 144-153.

Omran, M. and John Pointon. 2004. Dividend Policy, Trading Characteristics and Share Price: Empirical Evidence from Egyptian Firms. International Journal of Theoritical and Applied Finance. Vol. 7, No. 2: 121-133.

P. D, Ni Putu Wida dan I Wayan Suartana. 2014. Pengaruh Kepemilikan Manajerial dan Kepemilikan Institusional pada Nilai Perusahaan. E-Jurnal Akuntansi Universitas Udayana. Vol. 9, No. 3: 575-590.

Rizqia, Dwita Ayu, Siti Aisjah, dan Sumiati. 2013. Effect of Managerial Ownership, Financial Leverage, Profitability, Firm Size, and Investment Opportunity on Dividend Policy and FirmValue. Research Journal of Finance Accounting. Vol. 4, No. 11: $120-130$.

Sari, Oktavina Tiara. 2013. Pengaruh Keputusan Investasi, Keputusan Pendanaan dan Kebijakan Dividen terhadap Nilai Perusahaan. Management Analysis Journal. Vol. 2, No. 2: 1-7.

Ulum, Ihyaul, Imam Ghozali \& Anis Chariri. 2008. Intellectual Capital and Financial Performance.

Ulupui, IG. K. A. 2007. Effect of Ratio Analysis Liquidity, Leverage, Activity, and Stock Return Profitabiltas against (Studies in Food and Beverage Companies by Industry Category Consumption goods on the JSE).

Vural, Gamze, Ahmet Gokhan Sokmen, and Emin Huseyin Cetenak. 2012. Affects of Working Capital Management on Firm's Performance: Evidence from Turkey. International Journal of Economics and Financial Issues. Vol. 2, No. 4: 488-495.

Widhiastuti, Ni Luh Putu dan Made Yenni Latrini. 2015. Pengaruh Return On Asset dan Intangible Asset terhadap Nilai Perusahaan dengan Corporate Social Responsibility sebagai Variabel Pemoderasi. E-Jurnal Akuntansi Universitas Udayana. Vol.11, No. 2:370-383.

Wijaya, Bayu Irfandi dan I.B. Panji Sedana. 2015. Pengaruh Profitabilitas Terhadap Nilai Perusahaan (Kebijakan Dividen dan Kesempatan Investasi sebagai Variabel Mediasi). E-Jurnal Manajemen Unud. Vol. 4, No. 12: 4477-4500.

Winarto, Jacinta. 2015. The Determinants of Manufacturer Firm Value in Indonesia Stock Exchange. International Journal of Information, Business and Management. Vol. 7, No. 4: 323-349.

Yuniasih, Ni Wayan, Dewa Gede Wirama, dan I Dewa Nyoman Badera. 2010. Eksplorasi Kinerja Pasar Perusahaan: Kajian berdasarkan Modal Intelektual (Studi Empiris pada Perusahaan Keuangan yang terdaftar di Bursa Efek Indonesia). Simposium Nasional Akuntansi XIII Purwokerto. 


\section{LAMPIRAN}

\section{Tabel 1 Hasil Uji Statistik Deskriptif}

\begin{tabular}{lccrcc}
\hline & $\mathrm{N}$ & Minimum & Maximum & \multicolumn{1}{c}{ Mean } & Std. Deviation \\
\hline FV & 132 & 0,39833 & 77,58249 & 3,3415772 & 7,12511900 \\
MOWN & 132 & 0,00000 & 0,25620 & 0,0210441 & 0,04614640 \\
DAR & 132 & 0,09767 & 0,76934 & 0,4370912 & 0,18245216 \\
ROA & 132 & 0,01393 & 0,40377 & 0,1200949 & 0,09242896 \\
SIZE & 132 & 25,30843 & 32,57904 & 29,0342448 & 1,76545202 \\
CAPEX & 132 & 0,03416 & 1,65141 & 0,5226176 & 0,36261902 \\
DPR & 132 & 0,02325 & 1,71751 & 0,3879718 & 0,26001734 \\
IA & 132 & $-3, \mathrm{E}+11$ & $3, \mathrm{E}+15$ & $4,63 \mathrm{E}+13$ & $2,615 \mathrm{E}+14$ \\
CR & 132 & 0,36239 & 11,74282 & 2,2926389 & 1,77409558 \\
AST & 132 & 0,04892 & 5,04936 & 1,2754280 & 0,89637705 \\
\hline SU
\end{tabular}

Sumber: Hasil pengolahan data SPSS v. 20

Tabel 2 Hasil Uji Statistik t

\begin{tabular}{lccl}
\hline \multicolumn{1}{c}{ Variable } & B & Sig. & \multicolumn{1}{c}{ Keterangan } \\
\hline (Constant) & 11,641 & 0,001 & \\
MOWN & $-9,967$ & 0,002 & Berpengaruh \\
DAR & 1,207 & 0,269 & Tidak Berpengaruh \\
ROA & 20,718 & 0,000 & Berpengaruh \\
SIZE & $-0,395$ & 0,000 & Berpengaruh \\
CAPEX & $-1,296$ & 0,004 & Berpengaruh \\
DPR & 0,859 & 0,128 & Tidak Berpengaruh \\
IA & $2,510 E-014$ & 0,000 & Berpengaruh \\
CR & $-0,036$ & 0,755 & Tidak Berpengaruh \\
AST & $-0,292$ & 0,097 & Tidak Berpengaruh \\
\hline
\end{tabular}

Sumber: Hasil pengolahan data SPSS v. 20 